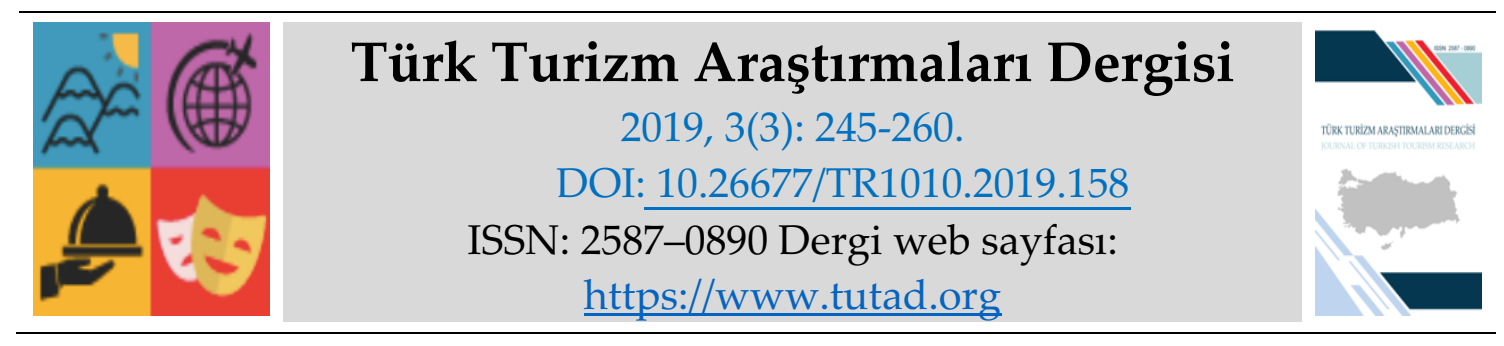

KAVRAMSAL MAKALE

\title{
Turizm Değer Zinciri Analizi Üzerine Kavramsal Bir Çerçeve
}

Öğr. Gör. Serap SERIN KARACAER, Aksaray Üniversitesi, Sosyal Bilimler MYO, Aksaray, eposta: sskaracaer@gmail.com ORCID: https://orcid.org/0000-0001-6730-2028

Prof. Dr. Yüksel ÖZTÜRK, Ankara Hacı Bayram Veli Üniversitesi, Turizm Fakültesi, Ankara, eposta: yukselozturk66@gmail.com

ORCID: https://orcid.org/0000-0002-4320-5626

\section{Öz}

Turizm sektörünün temel faaliyet alanı, herhangi bir nedenle daimi ikametgâhından geçici süreliğine ayrılmış bireylerin konaklama ve seyahat gereksinimlerini karşılamaya yönelik ürünleri sunan işletmeleri kapsamaktadır. Bu faaliyet alanlarına ilave olarak, turistik tüketicilere geniş kapsamlı bir seyahat deneyimi sunmaya yönelik çeşitli işletmeler ve kuruluşlar da (yeme-içme, eğlence, alış-veriş, spor, sağlık vb.) turizm sektörüne dâhil olabilmektedirler. Değer zinciri ise bir ürünün veya hizmetin kavramsal tasarımından nihai tüketiciye teslimine kadar gerekli olan tüm operasyonları tanımlamakta kullanılan bir kavramdır. Dolayısıyla turizm değer zincirini, turizm ürünlerinin üretilmesinden tüketicilere ulaştırılmasına kadarki süreçte yer alan tüm mal ve hizmet tedarikçilerinin faaliyetlerinden oluşan geniş kapsamlı bir zincir ağı olarak ifade etmek mümkündür. Çalışmada değer zinciri yaklaşımı kavramsal olarak ele alınmış olup, değer zinciri yaklaşımının bir hizmet sektörü olan turizme uygulanabilirliği ve sağlayabileceği katkıların irdelenmesi amaçlanmıştır. Bu bağlamda çalışma kapsamında nitel araştırma yöntemi esas alınmış olup, konuya ilişkin kaynak ve doküman incelemesi gerçekleştirilerek kavramsal bir çerçeve oluşturulmuştur. Çalışma neticesinde konaklama, yeme-içme, ulaşım, alış-veriş gibi faaliyet alanlarının turizm değer zincirinin birincil faaliyet unsurlarını oluşturdukları; turizmin destinasyonda gelişmesine katkı sağlayabilecek bir takım ulusal ve yerel kurum ve kuruluşların da (hükümet, yerel yönetimler, STK'lar, sağlık ve eğitim kurumları gibi) destek faaliyet unsurlarını oluşturduğu görülmüştür. Ayrıca çalışma bulgularına göre "her zincirin en zayıf halkası kadar güçlü olduğu" gerçeğinden hareketle turizm sektöründe küresel rekabeti sağlamanın kilit noktasının, zincirdeki bütün paydaşların ortak hareket etmesini sağlayabilmekten geçtiğini ifade etmek de mümkündür.

Anahtar Kelimeler: Turizm, Değer Zinciri, Turizm Değer Zinciri Analizi

Makale Gönderme Tarihi: 15.12.2018

Makale Kabul Tarihi: 03.07.2019

\section{Önerilen Atıf:}

Serin Karacaer, S. ve Öztürk, Y. (2019). Turizm Değer Zinciri Analizi Üzerine Kavramsal Bir Çerçeve, Türk Turizm Araştırmaları Dergisi, 3(3): 245-260.

(C) 2019 Türk Turizm Araştırmaları Dergisi. 


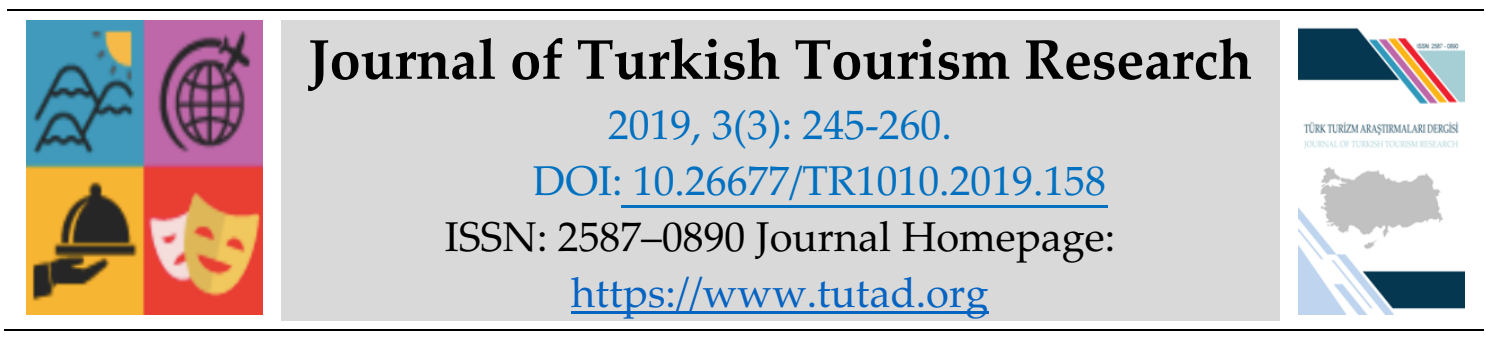

\title{
CONCEPTUAL PAPER
}

\section{A Conceptual Framework on Tourism Value Chain Analysis}

Lecturer Serap SERIN KARACAER, Aksaray Universty, Vocational School of Social Sciences, Aksaray, e-mail: sskaracaer@gmail.com ORCID: https://orcid.org/0000-0001-6730-2028

Prof. Dr. Yüksel ÖZTÜRK, Ankara Hacı Bayram Veli Universty, Ankara, e-mail: yukselozturk66@gmail.com ORCID: https://orcid.org/0000-0002-4320-5626

\begin{abstract}
Main field of activity of tourism sector comprises enterprises which offer products intended for meeting the accommodation and travel needs of individuals who have temporarily left their permanent residences for any reason. In addition to these fields of activity, various enterprises and establishments (such as foodbeverage, entertainment, shopping, sports, health) intended for offering an all-inclusive travel experience to touristic consumers can also be included in the tourism sector. Value chain, on the other hand, is a concept used in defining all necessary operations of a product or a service, from conceptual design to delivery to the final consumer. Thus, it is possible to express the tourism value chain as an extensive chain network including the activities of all goods and service suppliers in the process from the production of tourism products to delivery to the consumers. In this study, the value chain approach is discussed conceptually, and the objective of the study is to examine the applicability of the value chain approach to tourism, which is a service sector, and the contribution thereof. In this context, a qualitative research method has been based on within the scope of the study and a conceptual framework has been formed by carrying out a resource and document review related to the subject. As a result of the study, it has been seen that the activities such as accommodation, refreshments, transportation and shopping constitute the primary activity elements of the tourism value chain, and that a number of national and local institutions and organizations (such as government, local governments, NGOs, health and educational institutions) that will be able to contribute to the development of tourism in the destination constitute the elements of the supportive activities. It is also possible to state that the key point of ensuring global competition in the tourism sector is to ensure that all stakeholders in the chain are able to act jointly, based on the fact that "each chain is as strong as its weakest link."
\end{abstract}

Keywords: Tourism, Value Chain, Tourism Value Chain Analysis

Received: 15.12 .2018

Accepted: 03.07.2019

Suggested Citation:

Serin Karacaer, S. and Öztürk, Y. (2019). A Conceptual Framework on Tourism Value Chain Analysis, Journal of Turkish Tourism Research, 3(3): 245-260.

(C) 2019 Türk Turizm Araştırmaları Dergisi. 


\section{Gíriş}

Turizm sektörü seyahat acentaları, uluslararası havayolları, konaklama işletmeleri ve hatta destinasyonda turizm faaliyetlerine dahil olan yerel halkın da içinde bulunduğu bir dizi hizmeti içeren bir sektördür (Spenceley, Ashley ve Kock, 2009: 15). Turizm; 2017 yılı verileri itibariyle dünya genelinde 1.323 milyon uluslararası ziyaretçi sayısına ulaşan ve son yedi yıl boyunca kesintisiz büyümesini sürdüren bir hizmet sektörüdür. Turizm sektörü; uluslararası turistlerin destinasyonlarda gerçekleştirdikleri konaklama, yiyecek ve içecek, eğlence, alışveriş ve diğer turistik mal ve hizmetlerle ilgili harcamalariyla 1.340 milyar dolar ve buna ek olarak 240 milyar dolarlık yurt dışı destinasyonlara yapılan uluslararası yolcu taşımacılığı hizmetleri ile geliri toplamda 1.6 trilyon doları bulan bir sektördür. Sektör bu boyutu ile dünya hizmet ihracatının \%7'lik kısmını oluşturan, otomotiv ve yiyecek sektörlerini geride bırakarak kimyasal maddeler ve yakıtlardan sonra üçüncü sıraya yerleşmiş önemli bir ihracat kategorisidir. Aynı zamanda dünyada çalışan her on kişiden biri turizm sektöründe istihdam olanağ 1 bulmaktadır (www2.unwto.org). Bütün bu istatistikler dikkate alındığında turizm sektörü özellikle az gelişmiş ya da gelişmekte olan pek çok ülke açısından istihdam oluşturmada ve döviz geliri sağlanmasında en önemli kaynaklardan birisi durumundadır. Turizm sektörünün emek yoğun üretim yapısı dikkate alındığında söz konusu ülkeler açısından işsizlik sorununun çözümü noktasında da kilit rol oynağı da göz ardı edilemez bir gerçektir (Çil Yavuz, 2006; Bahar ve Kozak, 2007: 61; Perles-Ribes, Ramon-Rodriguez, Sevilla-Jimenez ve Moreno-Izquierdo, 2016; Kakoudakis, McCabe ve Story, 2017; Ilgaz Yıldırım, Yıldırım ve Gülmez, 2017).

Turizm sektörü, sunduğu ürün ve hizmetlerin bir gereği olarak birçok alt sektör ile ilişki içerisinde olan bir hizmet sektörüdür. Çünkü sektörün arzını oluşturan "turistik ürün", bileşik ürün özelliğini taşımaktadır. Başka bir ifade ile seyahate çıan bireyler, bu süre içerisinde ulaşım, konaklama, eğlence, yeme-içme gibi aslında her biri kendi başına bağımsız birer sektör olan hizmetleri bir arada toplu halde alma eğilimindedirler (Samırkaş ve Bahar, 2013: 2; Mete ve Acuner, 2014). Diğer yandan turistik tüketicilere tüm bu ürün ve hizmetlerin sunulmasında, turizm sektörü ile bire bir bağlantılı olmayan ancak, sektöre bir şekilde dahil olan bir takım sektörler ya da kurum ve kuruluşlar da (inşaat, sanayi, bankacılık, yerel yönetimler, sivil toplum kuruluşları gibi) söz konusudur. Dolayısıyla; turizm doğrudan ve dolaylı olarak tarım, imalat, ulaşım, ticaret, inşaat, konaklama, yeme-içme, iletişim, bankacılık, sağlık hizmetleri gibi birçok sektörü yayılma etkisi sonucu etkileyen bir sektördür (Proença ve Soukiazi, 2008: 792). Turizm sektöründe, sadece iki koldan (turistler ve sektörün yaptığı) yapılan harcamalar 70'e yakın iş alanını etkilemektedir (Goeldner ve Ritchie, 2009: 400). Bu bağlamda turizm sektörü için, sektörün doğrudan ya da dolaylı bir şekilde bağlantılı olduğu alt sektörleri, kurum ve kuruluşları ve paydaşları kapsayan bir “Değer Zinciri” modelinin oluşturulması kaçınılmazdır.

\section{DEĞER ZİNCİRI KAVRAMI}

Değer zinciri kavramının somut gerçekliğe sahip bir anlamı olmamakla birlikte, sadece iş dünyasının nasıl işlediğini anlamaya yarayan bir çerçeve çizmektedir (Mitchell, 2012). Bu bağlamda değer zinciri kavramı; bir mal ya da hizmet geliştirmek için farklı üretim aşamalarından nihai tüketicilere ulaşıncaya ve kullanım sonrası geri dönütlere kadar gerekli olan tüm faaliyetleri tanımlayan bir kavramdır (Kaplinsky ve Morris, 2000: 4; Hellin ve Meijer, 2006; Mitchell, 2012; El-Sayed, Dickson ve El-Naggar, 2015; Guabiroba, Meireles da Silva, Cesar ve Vieira da Silva, 2017).

Genel bir bakış açısı ile basit bir değer zinciri Şekil 1'de görüldüğü gibi açıklanabilir. Buna göre, bir mal ya da hizmetin üretim aşaması bir dizi bağlantıdan sadece birisidir. Ayrıca zincirin her 
bir bağlantısı çeşitli faaliyet alanlarından oluşmaktadır. Değer zinciri genellikle dikey bir zincir olarak tasvir edilmesine rağmen zincir içi bağlantılar çoğunlukla iki yönlü niteliktedir. Şekil 1'de ana hatları ile bir değer zincirini tasvir etmekle birlikte, değer zincirleri uygulandığı iş alanına göre çok fazla bağlantı içererek daha karmaşık bir yapıya sahip olabilirler.

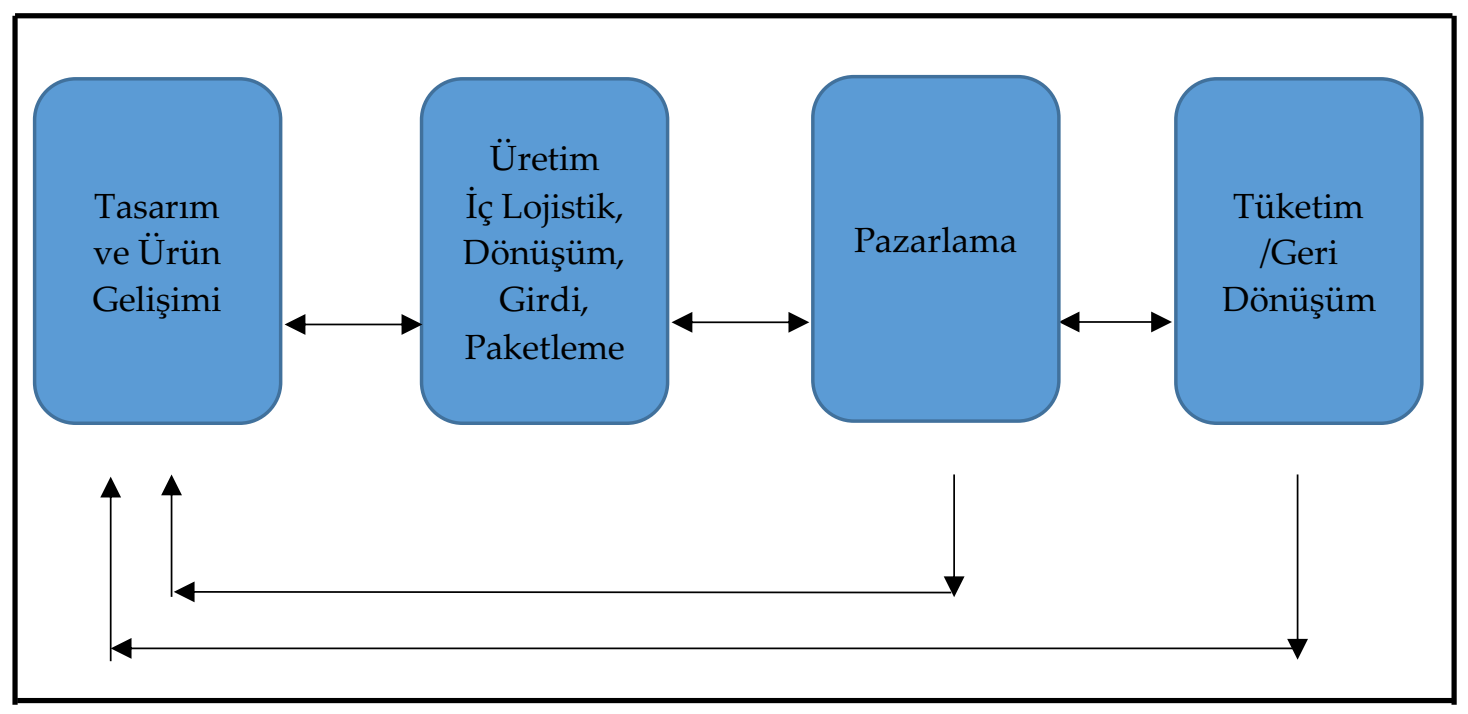

Şekil 1: Değer Zincirinin Genel Yapısı

Kaynak: Kaplinsky ve Morris, 2000: 4

Değer zinciri kavramı son yıllarda piyasa koşullarındaki büyük değişikliklerin bir yansıması olarak gündeme gelmiş bir kavram olarak görülse de yıllar içerisinde bir sistem olarak farklı bakış açıları ile alınmış bir kavramdır. Bu bağlamda Tablo 1'de değer zincirini ele alan bakış açıları özetlenmiştir. Buna göre (Raikes, Jensen ve Ponte, 2000; Kaplinsky ve Morris, 2000: 4; Mitchell, 2012):

Filière Yaklaşımı (1960): Bu yaklaşım 1960'lı yıllarda özellikle Fransa'nın eski sömürgelerinde pamuk, kauçuk, kakao, kahve gibi tarımsal mal ihracatlarının analiz kapsamını tanımlamak için kullanılmıştır. Bu kavram; tarımsal ürünlerin üretim ve dağıtım sistemlerinin ekonomik süreçlerinin daha kapsamlı anlaşılabilmesini sağlamak üzere özellikle tarımsal araştırmalarda kullanılmıştır. Söz konusu yaklaşım, ulusal sınırlar içerisinde kalarak yerel değer zincirlerine uygulanmış bir yaklaşımdır (Raikes ve diğ., 2000).

Emtia Zinciri (1974): 1970'lerde Wallerstein (1974) tarafından geliştirilen yaklaşım, dünya sistemleri teorisine dayalı, bağımlılık teorisinin bir detayıdır. Söz konusu yaklaşım, kapitalist dünya ekonomisinde değer zinciri dağılımının dinamiklerini açılamayı amaçlamaktadır. Yaklaşımın temel itici gücü; bir zincir içindeki üretim faaliyetlerine ve emek-yoğun faaliyetlere bağlı olarak farklı bölgeler arasındaki uluslararası iş bölümünün sağlanabilmesini mümkün kılmaktır. Bu bağlamda yaklaşım şirketlere; tedarik zinciri yönetimi ve dış kaynak kullanımı yoluyla işletme içi ve dışı yeterliliklerini de dikkate alarak "yap ya da al" bakış açısı ile hareket etmelerini tavsiye etmektedir. 1970'ler ile birlikte giyim sektöründe hız kazanmaya başlayan yaklaşım, süreç içerisinde tüketici elektroniği, ayakkabı, oyuncak gibi sektörlerde de yaygınlık kazanmıştır. 
Tablo 1: Değer Zinciri Kavramına İlişkin Bakış Açıları

\begin{tabular}{|c|c|c|c|c|c|c|}
\hline & $\begin{array}{c}\text { Filière } \\
\text { Yaklaşımı } \\
\text { (1960) }\end{array}$ & $\begin{array}{c}\text { Emtia } \\
\text { Zinciri } \\
(1974)\end{array}$ & $\begin{array}{l}\text { Değer } \\
\text { Zinciri } \\
(1980)\end{array}$ & $\begin{array}{c}\text { Küresel } \\
\text { Emtia } \\
\text { Zinciri } \\
\text { (1990) } \\
\end{array}$ & $\begin{array}{c}\text { Dünya } \\
\text { Ekonomik } \\
\text { üçgeni } \\
\text { (2000) } \\
\end{array}$ & $\begin{array}{c}\text { Küresel } \\
\text { Değer } \\
\text { Zinciri }\end{array}$ \\
\hline $\begin{array}{c}\text { Kavramsal } \\
\text { Çerçeve }\end{array}$ & $\begin{array}{l}\text { Birleşmemiş } \\
\text { teorik } \\
\text { yaklaşım, }\end{array}$ & $\begin{array}{l}\text { Bağımlılık } \\
\text { teorisinden } \\
\text { türemiş } \\
\text { dünya } \\
\text { sistemleri } \\
\text { teorisi, }\end{array}$ & $\begin{array}{l}\text { Birleşmemiş } \\
\text { teorik temel, }\end{array}$ & $\begin{array}{l}\text { Dünya } \\
\text { sistemleri } \\
\text { teorisi, } \\
\text { Örgütsel } \\
\text { sosyoloji, } \\
\end{array}$ & $\begin{array}{l}\text { Dünya } \\
\text { sistemleri } \\
\text { teorisi, } \\
\text { Örgütsel } \\
\text { sosyoloji, } \\
\end{array}$ & $\begin{array}{l}\text { Küresel } \\
\text { emtia } \\
\text { zincirleri, }\end{array}$ \\
\hline Hedefler & $\begin{array}{l}\text { Fiziksel } \\
\text { girdi- } \\
\text { çlktılar, fiyat } \\
\text { ve } \\
\text { pazarlama } \\
\text { zincirindeki } \\
\text { katma } \\
\text { değer, } \\
\text { Tarımsal } \\
\text { ürünlere } \\
\text { odaklanma, } \\
\end{array}$ & $\begin{array}{l}\text { Dünya } \\
\text { kapitalist } \\
\text { ekonomi } \\
\text { sisteminin } \\
\text { açıklanması, }\end{array}$ & $\begin{array}{l}\text { Endüstri } \\
\text { firmalarına } \\
\text { odaklanma, } \\
\text { Faaliyetlerin } \\
\text { katma } \\
\text { değerini } \\
\text { indirerek } \\
\text { rekabet } \\
\text { avantajı } \\
\text { sağlama, }\end{array}$ & $\begin{array}{l}\text { Küresel } \\
\text { bağlantılı } \\
\text { üretim } \\
\text { sistemleri } \\
\text { güç ilişkileri } \\
\text { (orta ve } \\
\text { mikro } \\
\text { seviyede), } \\
\text { Endüstriyel } \\
\text { mallara } \\
\text { odaklanma, }\end{array}$ & $\begin{array}{l}\text { Bölgeleri ya } \\
\text { da kümeleri } \\
\text { yükseltme, } \\
\text { Bağlayıcı } \\
\text { küme } \\
\text { geliştirme } \\
\text { ve değer } \\
\text { zincirleri, }\end{array}$ & $\begin{array}{l}\text { Yönetim ve } \\
\text { düzenleme } \\
\text { sistemleri, } \\
\text { Yatay ve } \\
\text { dikey } \\
\text { yaklaşımları } \\
\text { bağlamak, }\end{array}$ \\
\hline $\begin{array}{c}\text { Temel } \\
\text { Kavramlar }\end{array}$ & $\begin{array}{l}\text { Altında } \\
\text { yatan temel } \\
\text { bir kavram } \\
\text { yok (Nötr), }\end{array}$ & $\begin{array}{l}\text { Uluslararası } \\
\text { iş bölümü, } \\
\text { Çekirdek } \\
\text { çevre, } \\
\text { Yarı çevre, }\end{array}$ & $\begin{array}{l}\text { Kurum içi } \\
\text { katma değer } \\
\text { kavramı, }\end{array}$ & $\begin{array}{l}\begin{array}{l}\text { Yönetim } \\
\text { (tüketici } \\
\text { odaklı/alıcı } \\
\text { odaklı), }\end{array} \\
\text { Örgütsel } \\
\text { öğrenme } \\
\text { /yükseltme, }\end{array}$ & $\begin{array}{l}\text { Yönetim, } \\
\text { Kümenin } \\
\text { yükseltilme } \\
\text { si, }\end{array}$ & $\begin{array}{l}\text { Yönetim, } \\
\text { İşlem } \\
\text { maliyetleri, } \\
\text { Yükseltme, }\end{array}$ \\
\hline Özellikler & $\begin{array}{l}\text { Statik (sabit) } \\
\text { model, } \\
\text { Ulusal } \\
\text { sinirlar, }\end{array}$ & $\begin{array}{l}\text { Bütünsel } \\
\text { bakış açısı, } \\
\text { Makro } \\
\text { yönelim, } \\
\text { Nitel analiz, }\end{array}$ & $\begin{array}{l}\text { Firma } \\
\text { düzeyinde } \\
\text { sinurlı } \\
\text { üretim } \\
\text { süreçleri, } \\
\text { Uluslararası } \\
\text { bölgesel } \\
\text { düzenlemel } \\
\text { erde } \\
\text { dikkatsizlik, }\end{array}$ & $\begin{array}{l}\text { Yönetime } \\
\text { odaklanma, }\end{array}$ & Nitel analiz, & $\begin{array}{l}\text { Emtia } \\
\text { zincirinin } \\
\text { bileşimi, } \\
\text { Küresel } \\
\text { emtia } \\
\text { zinciri, } \\
\text { Dünya } \\
\text { ekonomik } \\
\text { üçgeni, }\end{array}$ \\
\hline $\begin{array}{l}\text { Anahtar } \\
\text { Yazarlar }\end{array}$ & $\begin{array}{l}\text { Raikes, } \\
\text { Jensen ve } \\
\text { Ponte (2000) }\end{array}$ & $\begin{array}{l}\text { Wallerstein } \\
(1974)\end{array}$ & $\begin{array}{l}\text { Michael } \\
\text { Porter } \\
(1985)\end{array}$ & $\begin{array}{l}\text { Gereffi } \\
\text { (1994) }\end{array}$ & $\begin{array}{l}\text { Messner } \\
(2002)\end{array}$ & $\begin{array}{l}\text { Gereffi ve } \\
\text { Kaplinsky } \\
\text { (2001), } \\
\text { Humphrey } \\
\text { ve Schmitz } \\
\text { (2000), } \\
\text { Gereffi, } \\
\text { Humphrey } \\
\text { ve Sturgeon } \\
\text { (2005) }\end{array}$ \\
\hline
\end{tabular}


Değer Zincir (1980): 1980'li yılların ortalarında Porter (1985), rekabet avantajı konusundaki çalışmaları bağlamında değere zinciri kavramını geliştirmiştir. Porter değer zinciri yaklaşımı çerçevesinde, şirketlerin işletme değerlerini arttırabilmeleri için belirli faaliyetlerini analiz etmeleri gerekliliği üzerinde durmuştur. Bu bağlamda Porter işletmelere değer sağlayacak faaliyetleri, birincil faaliyetler ve destek faaliyetler olmak üzere iki önemli kategoriye ayırmıştır. Porter'ın değer zinciri analizi yaklaşımı; yerel rekabet ve özel talep koşullarının önemini vurgulamaktadır. Bu bağlamda söz konusu yaklaşımın, ekonomik kalkınma ve kümelenme düşüncesi üzerinde büyük etkisi olmuştur.

Küresel Emtia Zinciri (1990): 1990'larda Gereffi (1994: 97), temel olarak Wallerstein'in emtia zincirini esas alarak türettikleri küresel emtia zincirini geliştirmiştir. Gereffi yaklaşımı; (1) girdiçıktı yapısı, (2) uluslararası yapı, (3) kurumsal yapı ve (4) yönetim yapısı olmak üzere dört unsur üzerinden kurulmuştur. Söz konusu yaklaşımda; işletmeler arası ilişkiler ve kurumsal işleyişi dikkate alan yönetim üzerine odaklanılmıştır. Gereffi bu yaklaşım ile tüm dünyada dağılmış şekilde bulunan ancak aslında birbirleriyle bağlantılı olan üretim sistemlerinin gücünün dengeli bir koordinasyon yoluyla sağlanabileceğini savunmuştur. Çalışma kapsamında Gereffi, zincirde bulunan bazı baskın aktörlerin zincirin genel karakterini belirlediği ve bu aktörlerin zincir içerisindeki olasılıkları, bilgi aktarımını ve etkileşimi de sağladıkları sonucuna ulaşmıştır.

Dünya Ekonomik Üçgeni (2000): Bu yaklaşım Gereffi'nin küresel emtia zinciri yaklaşıma dayanarak Messner (2002) tarafından geliştirilmiştir. Messner (2002) dünya ekonomik üçgeni yaklaşımı ile zincirdeki aktörlerin, yönetimin ve düzenleme sistemlerinin küresel emtia zincirindeki faaliyetlerin kapsamını belirlediği görüşünü savunmuştur. Söz konusu yaklaşım, tüm bölgeleri ya da kümeleri zincire entegre ederek iyileştirmeye odaklanır. Bu bağlamda yaklaşım çerçevesinde, yatay (kümelenme gelişimi) ve dikey (değer zinciri) yaklaşımlar birbirine bağlanmıştır.

Küresel Değer Zinciri: Küresel değer zinciri yaklaşımının merkezinde "yönetim" kavramı yer almaktadır. Söz konusu yaklaşımda yönetim (denetim) kavramı, zincirdeki faaliyetlerin piyasa dışı koordinasyonunun gerçekleştiği kurumlar arası ilişkilerin ve kurumsal işleyiş̧in yürütülmesinde önem taşımaktadır. Yönetim (denetim) kavramı sayesinde zincirdeki bazı şirketler, zincirdeki diğer paydaşların çalıştı̆̆ı parametreleri ayarlayabilmekte ya da uygulayabilmektedirler. Yaklaşıma göre; zincirdeki faaliyetler ancak farklı ülkelerde ya da bölgelerde yürütülebildiğinde söz konusu değer zinciri "küresel" bir nitelik taşıyabilecektir. Küresel değer zinciri yaklaşımına göre yönetimsiz (denetimsiz) bir zincirin, sadece bir pazar ilişki dizisi olmaktan öteye gitmesi mümkün görünmemektedir.

Değer zincirine ilişkin bu farklı süreçlerde; işletmeler arasında artan rekabet ve değer zincirlerinin geçirdiği evrimler, yeni ve mevcut girişimciler açısından hem zorluklar hem de yeni fırsatlar ile sonuçlanmıştır. Değer zinciri kavramına ilişkin teorik çalışmalar, düşük gelir seviyesine sahip birçok ülkenin küresel değer zincirlerine dâhil edilmeleri ile büyüme hızını yakalayabilecekleri yönündedir. Diğer yandan söz konusu bu çalışmalarda, endüstriyel kalkınmanın sağlanmasında geçmişte kullanılan bir takım yöntemlerin geçerliliğini yitirdiği kabul edilmektedir (Mitchell, 2012).

\section{DEĞER ZİNCİRİ ANALİŻ}

Değer zinciri analizini; işletmenin stratejik açıdan önemli faaliyetlere bölümlenmesi ve bu faaliyetlerin, maliyetlerin değişimleri ve farklılaştırma üzerindeki etkilerinin incelenmesi amacıyla kullanılan bir yöntem olarak tanımlamak mümkündür (Hergert ve Morris, 1989). Daha geniş bir bakış açısı ile değer zinciri analizini; işletmenin rekabet avantajının anlaşılması, değer 
zincirinin hangi aşamasında müşterilere sunulan değerin artırılabileceğinin veya maliyetlerin düşürülebileceğinin belirlenmesi ve işletmenin tedarikçileriyle, müşterileriyle ve sektördeki diğer işletmelerle olan ilişkilerinin daha iyi bir şekilde anlaşılması amacıyla kullanılan stratejik bir araç olarak tanımlamak mümkündür (Blocher, Stout ve Cokins, 2010: 40). Değer zinciri analizi, zincirdeki farklı basamaklar ile paydaşları tanımlamayı ve bunların performanslarını değerlendirmeyi amaçlamaktadır (Jaligot, Wilson, Cheeseman, Shaker ve Stretz, 2016) .

Her işletme ürününü tasarlamak, üretmek, pazarlamak, sunmak ve desteklemek üzere birtakım faaliyetler gerçekleştirir. İşletmeler, söz konusu tüm bu faaliyetleri bir değer zinciri kullanarak sunabilirler (Porter, 1985: 36). Bu bağlamda Porter (1985: 37) işletmelerin faaliyet unsurlarını ve bu unsurlar arasındaki bağlantıları genel hatları ile ortaya koyan bir değer zincirini Şekil 2'de görüldüğü üzere tasvir etmiştir. Porter'a göre; bir işletmenin değer zinciri ve bireysel faaliyetlerini gerçekleştirme biçimi o işletmenin tarihçesinin, stratejisinin, stratejisini uygulama yaklaşımının ve ekonomik faaliyetlerinin bir yansımasıdır.

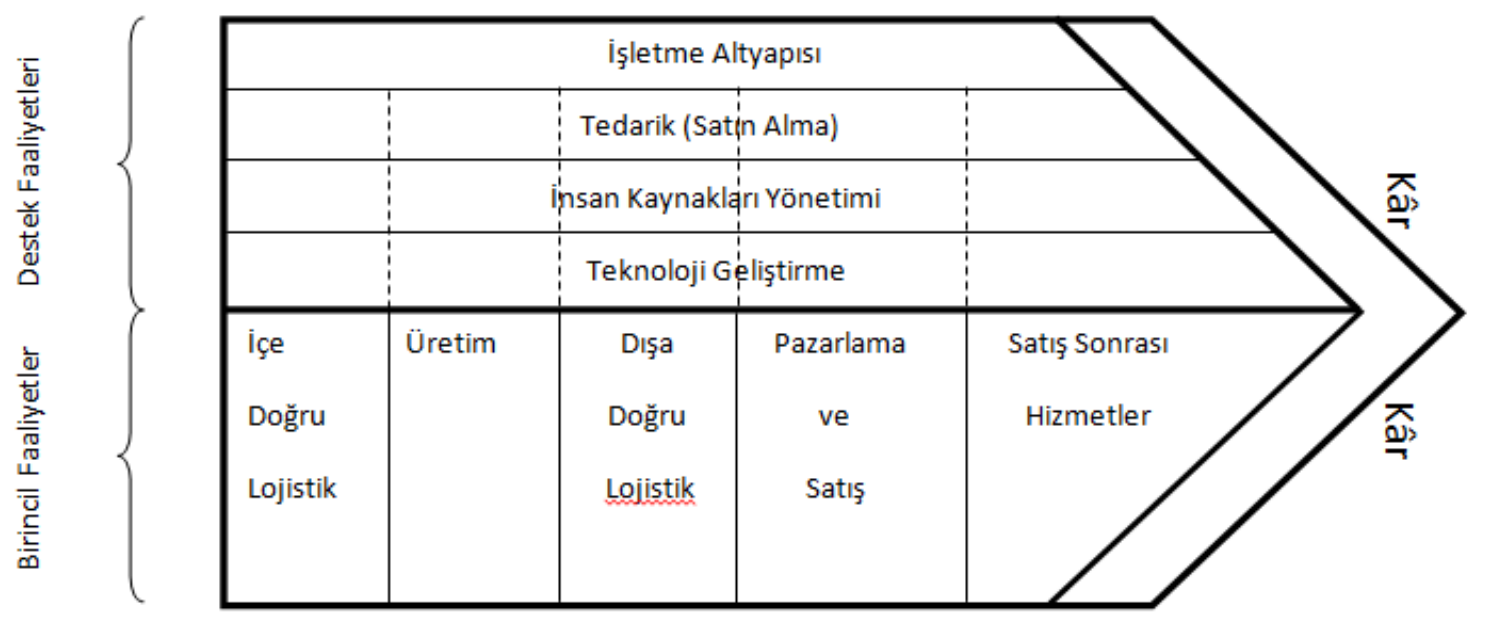

Şekil 2: Porter'ın İşletmeler İçin Değer Zincir Modeli

Kaynak: Porter, 1985: 37

Porter (1985) tarafından geliştirilen değer zinciri modelinde görüldügü üzere (Şekil 2) değer zinciri analizlerini yürütebilmek için, firmanın operasyonlarının birincil ve destekleyici faaliyetler başlıkları altında incelenmesi gerekmektedir. Birincil faaliyetler işletmenin üretimi ile ilişkili olan operasyonlar; destekleyici faaliyetler ise işletmenin etkinliği ve etkisi için gerekli olan altyapıya yönelik operasyonlardır.

Değer zinciri analizi; bir işletmenin kendi sunduğu servis ya da ürünlere belirli bir sırayla uyguladığı işlemlerin, bu sıralama ile zincirdeki güçlü ve zayıf yönlerini sistematik olarak ortaya çıkarmak, tanımlamak ve analiz etmek için kullanılan bir analiz yöntemidir. Değer zinciri analizi, işletme işlemlerini birer zincir halkası olarak görür ve her bir halkanın değerini artırmayı hedefler (Dekker, 2003). Bir değer zinciri oluşturmanın ana unsuru, bir işletmenin belirli bir sektördeki faaliyetleridir. Sektör çapında değer zinciri oluşturmak da mümkün olmakla beraber, sektördeki her bir işletmenin kendi faaliyet alanı doğrultusunda değer zinciri oluşturması daha uygundur. Çünkü sektör düzeyindeki bir değer zinciri çok geniş çaplı olacağından rekabet avantajı oluşturabilecek önemli kaynakların belirsizleşmesine neden olabilmektedir. Aynı zamanda rakip değer zincirleri arasındaki farklar, rekabet avantajının da temel kaynağını oluşturmaktadır. Ayrıca aynı sektördeki benzer işletmelerin bile faaliyet unsurlarında ayrımlar söz konusu 
olabileceğinden, işletme düzeyinde değer zinciri oluşturulması daha uygun bir stratejidir (Porter, 1985: 38).

Değer zinciri analizi, işletmelerin rekabet stratejileri noktasında avantaj sağlayan önemli bir yöntemdir. Herhangi bir ürünün müşteriye sunulduğu zincirin tamamını tanımlamaya çalışan değer zinciri analizinin bir takım önemli görevleri söz konusudur. Bu görevleri; mevcut faaliyetleri denetlemek, gelecekteki faaliyetleri geliştirmek, değer yaratan faaliyetleri belirlemek, müşteri ihtiyaçlarının tatminine toplam katkısını analiz etmek, sistematik bir yol sunmak ve rakiplerin değer zinciri ile karşılaştırma yapmak olarak sıralamak mümkündür (Dekker, 2003). Söz konusu bu görevler ve özellikle de tüm dünyada küreselleşmenin hızlı bir şekilde devam ettiği dikkate alındığında, değer zinciri analizinin neden önemli olduğunu üç temel unsur üzerinden açıklamak gerekmektedir (Kaplinsky ve Morris, 2000: 9). Bunlar;

1) Büyüyen iş bölümü ve bileşenlerin üretimin küresel dağılımı ile sistematik rekabetçilik giderek daha da önemli hale gelmiştir. Değer zinciri analizi sistematik rekabetçiliğin kapsamını ve gerekliliklerini anlamada önemli bir rol oynamaktadır. Değer zinciri analizi ile temel yeterliliklerini tanıma ve analiz etme imkânı bulan işletme, kendine özgü yeterlilikler kapsamında olmayan işlevleri dış kaynaklara yönlendirecektir. Ayrıca, üretim zincirindeki mal ya da hizmet girdilerinin akışını haritalamak, işletmenin tutum ve davranışı hakkında da bilgi sahibi olunmasını sağlayacaktır. Dolayısıyla kendi işlevlerinde değer zincirini içselleştiremeyen işletmelerin, verimliliklerini yükseltme noktasında çabalamaları çok da etkili sonuçlanmayacaktır (Kaplinsky ve Morris, 2000: 11-12).

2) Üretimde verimlilik, küresel pazarlara başarılı bir şeklide nüfus edebilmek adına öncelikli gerekliliktir. Değer zinciri analizinin önemli olmasının ikinci nedeni, hizmetlerden ziyade üretimde uzmanlaşmış işletme ya da ülkelerin nihai pazarlara bağlanma şekilleri ve küresel pazarlara katılma yetenekleri noktasında sahip oldukları avantaj ve dezavantajları anlamalarına yardımcı olmasıdır (Kaplinsky ve Morris, 2000: 11).

3) Küreselleşmenin en iyisini yapmak üzere sürekli gelir büyümesine izin veren küresel pazarlara giriş, değer zincirindeki tüm dinamiklerin anlaşılmasını gerektirmektedir. Değer zinciri analizinin önemli olmasının üçüncü nedeni ise, faydaların özellikle de gelirlerin küresel ekonomiye katılanlara dağılımının açıklamaya yardımcı olmasıdır. Bu durum, bireysel üreticilerin ve ülkelerin kazanımlarındaki paylarını arttırmalarına olanak sağlayacak politikaları tanımlamalarını kolaylaştıracaktır (Kaplinsky ve Morris, 2000: 11).

Değer zinciri analizi aynı zamanda, işletmelerin uyguladıkları stratejik faaliyetlerin işletmelerin misyon, vizyon ve hedeflerine ne ölçüde uygun ve destek olduğunun belirlenmesinde de etkin bir yöntemdir (Evans, Campbell ve Stonehouse, 2004: 66). Ayrıca söz konusu analiz, müşterilere değer vermenin farklı ve yararlı başka yollarının olduğunun da araştırılmasına olanak tanımaktadır (Walters ve Jones, 2001).

\section{TURİZMDE DEĞER ZİNCİRI ANALİŻ}

Değer zinciri modeli özellikle üretim odaklı çeşitli sektörlerde uygulanmış olmakla beraber, hizmet odaklı sektörlerde çok da fazla çalışılmamış bir modeldir. Hizmet sektörünün önemli unsurlarından olan turizm sektöründe sunulan turistik ürünlerin, sektörün yapısına uygun olarak bileşik ürün özelliği taşıması, değer zinciri modelinin turizme de uygulanabileceğinin bir göstergesidir (Mete ve Acuner, 2014). Turizm sektörünün ana aktörleri ve paydaşları, turistlerin 
ülkelerindeki tur operatörlerinden en küçük turizm destinasyonlarındaki yerel restoranlar ve satıcılara kadar uzanan büyük bir turizm değer zincirinin parçasıdır (Slob ve Wilde, 2006).

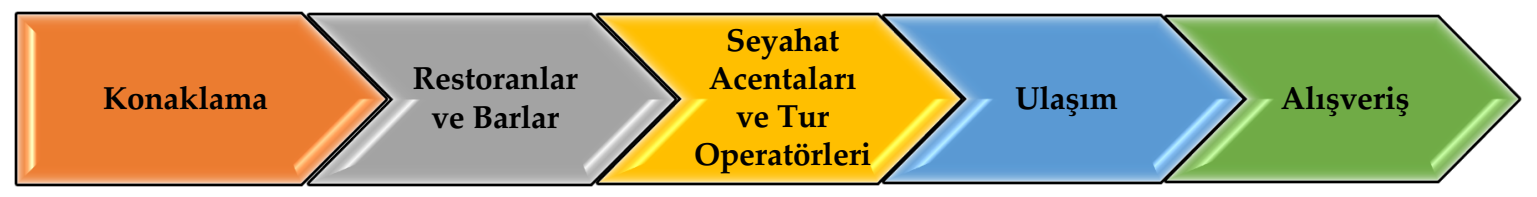

Şekil 3: Turizm Değer Zincirinin Ana Unsurları

Kaynak: Vignati ve Laumans, 2010: 6

Değer zinciri analizleri, herhangi bir ürünü ham halinden nihai tüketime kadar getiren süreçte gerçekleşen faaliyetler sırasındaki çeşitli bağlantıları incelemektedir. Ancak turizm ürünlerinin doğası gereği (üretildiği yerde tüketilmesi, stoklanamaması gibi), turizm değer zinciri analizini sanayi ya da tarım sektörlerinde kullanılan değer zinciri analizlerinden farklılaştırmaktadır (Travers, 2007: 14; Ashley ve Mitchell, 2008: 4). Turizm sektörü içerisinde mal ya da hizmet üreten işletmeler büyük oranda bütünleşmiş ve yoğun olarak birbirine bağlı alt sektörlerden oluşmaktadırlar (Mete ve Acuner, 2014). Bu duruma bağlı olarak turizm değer zinciri, turizm ürünlerinin üretilmesinden tüketicilere ulaştırılmasına kadarki süreçte yer alan tüm mal ve hizmet tedarikçilerinin faaliyetlerinden oluşmaktadır. Turizm değer zinciri; turizmin temel faaliyetleri olan konaklama, ulaşım, gezi gibi alanların yanı sıra yeme-içme, el sanatları, gıda üretimi, turizmi destekleyen altyapı (su, enerji, yol vb.), atık imhası gibi birçok bileşeni de içeren karmaşık bir yapıdadır (Slob ve Wilde, 2006: 8).

Turizm değer zinciri, turistik tüketicinin tatil tercihini belirlemesi ve rezervasyonunu yaptırması ile başlayan bir süreçtir. Turizm ürününü satın alma aşamasında turistik tüketici çeşitli alternatiflere sahiptir. Bu noktada turistik tüketici seyahat planını, tur operatörleri ya da seyahat acentaları yardımı ile gerçekleştirebileceği gibi kendisi bireysel olarak da gerçekleştirebilmektedir. Bir sonraki aşama turistik tüketicinin destinasyona varışını ve dönüşünü sağlayan ulaşım (uçak, tren, otobüs, araba gibi) şeklidir. Aynı zamanda tüketicinin destinasyonda geçirdiği sürece günlük geziler ya da transferi için kullanılan ulaşım şekilleri de turizm değer zincirinin bir parçasıdır. Destinasyona ulaşan turistik tüketici için konaklama ve bu süre içerisinde temel gereksinimi olan yeme-içmeye ilişkin faaliyetler en önemli unsurlardır. Dolayısıyla turizm değer zincirinin en önemli aşamalarından birisi de destinasyonda turistik tüketicinin konaklama ve yeme-içme faaliyetlerine hizmet verebilecek otel, pansiyon, tatil köyü, restoran, kafe gibi faaliyet unsurlarına ilişkin süreçtir. Destinasyonda geçirilen süre boyunca zincire dahil olan diğer önemli faaliyet alanlarından birisi turistik tüketicinin boş zaman etkinliklerini değerlendirebileceği çeşitli etkinlikler (gezi, eğlence, yerel organizasyonlar gibi) iken bir diğeri ise alış-veriş faaliyetleridir. Turistik tüketicinin özellikle yerel etkinliklere katılımı ve yerel alanlarda alış-veriş faaliyetlerini gerçekleştirmesi, destinasyonun ve destinasyonda ev sahibi konumunda olan yerel halkın sosyo-ekonomik gelişimi açısından da son derece önem arz etmektedir. Söz konusu tüm bu aşamalar turizm değer zincirinin birincil faaliyet unsurlarını oluştururken; turizmin destinasyonda gelişmesine katkı sağlayabilecek bir takım ulusal ve yerel kurum ve kuruluşlar da (hükümet, yerel yönetimler, STK'lar, sağlık ve eğitim kurumları gibi) turizm değer zincirinin destek faaliyet unsurlarıdır. 
Bu bağlamda Şekil 4'de turizm değer zincirinin birincil faaliyet unsurları (Mitchell ve Phuc, 2007: 16; Spenceley ve diğ., 2009: 29);

- Tatil Planlaması: Turistik tüketici tarafından gerçekleştirilen bir faaliyettir. Tüketici seyahat etmeye karar vermekte ve tur operatörlerini, seyahat acentalarını ya da çevrimiçi hizmetleri kullanarak seyahatini planlamaktadır. Bu noktada tatil planlaması sürecinin alt işlem basamakları; tur operatörleri, seyahat acentaları ya da çevrimiçi hizmetlerdir.

- Ulaşım: Turistik tüketici tarafından seçilen destinasyona ulaşmak için kullanılan tüm kara, deniz, demiryolu ve hava taşımacılığı faaliyetlerini içermektedir. Ulaşım, turizm değer zincirinde faaliyeti en büyük olan bağlantıdır. Ulaşım faaliyeti, destinasyona varmadan başlayan ve destinasyon terk edilinceye kadar devam eden bir faaliyet unsurudur.

- Konaklama ve Yeme-İçme: Konaklama, destinasyonda turistik tüketicinin barınma ihtiyacını karşılama hizmetini sağlayan faaliyet unsurlarını içermektedir. Konaklama unsurları, turizm değer zinciri içerisinde geniş çeşitliliğe ve büyük değere sahip faaliyet unsurlarıdır. Yeme-içme faaliyeti sunan işletmeler çeşitlilikleri ile karakterize edilen faaliyet unsurlarıdır. Söz konusu bu çeşitlilik içerisinde; özel işletmeler, kamuya bağlı kuruluşlar, bağımsız olarak işletilen küçük işletmeler ve büyük çok uluslu şirketler tarafından işletilen yeme-içme işletmeler yer alabilmektedir.

- Deneyimsel Etkinlikler ve Organizasyonlar: Büyük konserler, sergiler, film festivalleri gibi birçok organizasyon turizm değer zinciri içerisinde yer alan faaliyet unsurlarındadır. Aynı zamanda; tarihi ve kültürel alanlar, milli parklar, doğa-hava-su sporlarına bağlı etkinlikler, plaj-havuz etkinlikleri gibi turistik tüketiciye deneyim yaşatabilecek birçok boş zaman etkinliği de turizm değer zincirinin birer parçasını oluşturmaktadır.

- Alış-Verişs: Alış-veriş faaliyetleri turizm değer zinciri içerisinde çok önemli bir halkadır, çünkü ekonomik gücü söz konusudur. Destinasyona göre farklılık göstermekle birlikte hediyelik eşya, kuyum, yerel ve bölgesel ürünler, el sanatı ürünler gibi turistik tüketiciye ziyaretini anımsatıcı materyallere yönelik alış verişler özellikle destinasyondaki yerel halk açısından önemli bir ekonomik kazanım oluşturmaktadır.

Turizm değer zincirinde yer alan destek faaliyet unsurları ise;

- Turizm Bakanlığı: Ülkenin turizm olanaklarını tanıtmak ve pazarlamak, turizmin gelişimi için gerekli tedbirleri almak, devletin diğer kurum ve kuruluşları ile işbirliği yaparak onları turizme yöneltmek, turizm faaliyetlerine konu olan doğal, tarihi ve kültürel değerleri geliştirmek ve aynı zamanda korumak gibi faaliyetleri yürütmektedir.

- Yerel ya da Bölgesel Turizm Kurumlarn: Söz konusu kurumlar, destinasyonda yer alan ve hükümet ya da bakanlık düzeyinde turizm ile ilgili yapılan çalışmalara yerel ya da bölgesel (il turizm müdürlükleri gibi) katkı sağlama amacında olan kurumlardır.

- Turizm ve Seyahat Sektörü Kurum ve Kuruluşlari: Söz konusu kurum ve kuruluşlar; turizm ve seyahat sektöründe mesleki etik ve dayanışmanın sağlanması, mesleğin gelişimin sağlanması, meslek kuruluşlarının halkla ilişkilerinin geliştirilmesi, sektörler ile doğrudan ya da dolaylı bağlantılı kişi, kuruluş ve kurumların koordinasyonunun sağlanması, sektörlerin ulusal ya da uluslararası platformlarda temsil edilmesi ve sektörün ülke plan ve politikaları ile uyumlu hareket etmesini sağlama amacındadırlar. 


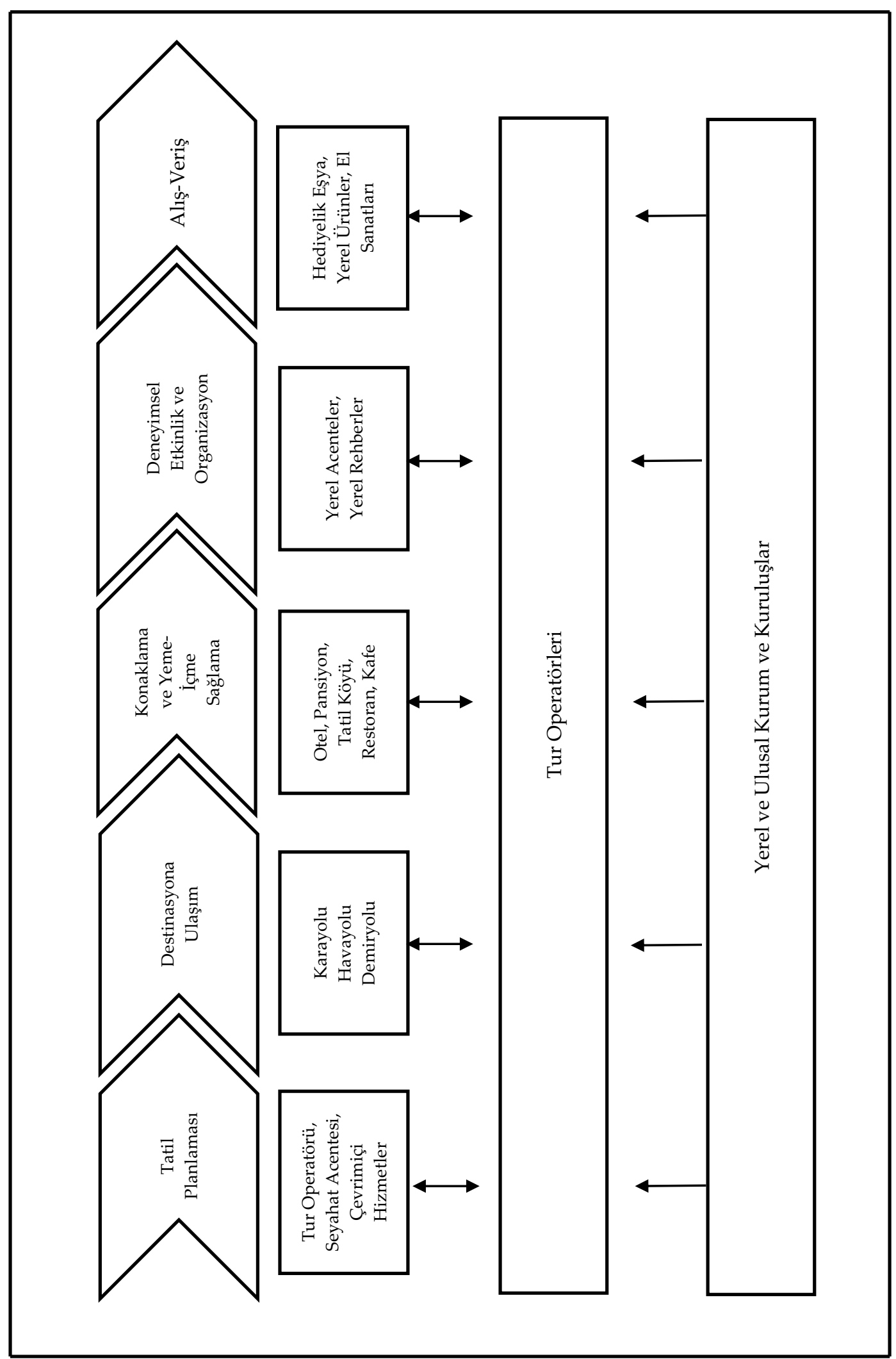

Şekil 4: Turizm Değer Zincirinin Faaliyet Unsurları

Kaynak: Springer-Heinze, 2007: 14 
- Diğer Kuruluşlar: Bu kapsamda; turizm sektörü ile gerek doğrudan gerekse de dolaylı olarak bir takım ilişkiler ve bağlantılar içerisinde olan ve aynı zamanda sektörün gelişmesine yönelik çalışmalar yürüten kuruluşlar yer almaktadır. Kalkınma ajansları, üniversiteler, turizm eğitimi ile ilgilenen diğer eğitim kurumları gibi kuruluşlar da turizm değer zincirinin birer parçasını oluşturabilmektedir (Mitchell, 2012; Mete ve Acuner, 2014).

Değer zinciri analizi bir takım gerekçeler ile turizm sektörünün gelişimine katkı sağlayabilmektedir. Söz konusu bu gerekçeleri şu şekilde sıralamak mümkündür (Mitchell, 2012):

- İlk olarak değer zinciri analizi özellikle destinasyonun ev sahibi yerel halkın yerel, bölgesel ya da uluslararası turizm ticareti ile ne kadar bağlantılı olduğu ve söz konusu bu ticari faaliyetlerden daha fazla nasıl yararlanabileceğinin anlaşılması için uygulanabilmektedir.

- İkinci olarak değer zinciri analizi; ticari canlılığa ve piyasalara odaklanması ile özünde "ekonomik canlılık ve sürdürülebilirlik" sağlayabilen bir analiz yöntemidir. Aynı zamanda değer zinciri, büyüme noktasında pazar geliştirme yaklaşımını benimseyen bir yöntemdir. Bu bağlamda turizm değer zinciri hem sektördeki işletmelerin hem de sektörden yararlanan grupların birbirleri ile etkileşimi için bir çerçeve sunmaktadır.

- Üçüncü olarak değer zinciri analizi başarılı bir şekilde kullanıldığında; belirli hedef gruplar açısından kritik konuların ve tıkanıklıkların belirlenmesinde, sonrasında ise güçlü ve etkili politika ve büyüme stratejilerinin oluşturulmasında oldukça iyi bir araçtır. $\mathrm{Bu}$ noktada turizm değer zinciri de sektör katılımcıları ve faydalanıcıları açısından problemli konuların tespit edilmesi ve somut müdahale stratejilerinin belirlenmesinde etkili bir yöntemdir. Özellikle de turizm faaliyetlerinin en önemli halkalarından birisi olan yerel halkın sektörden daha iyi koşullar nasıl yararlanabileceği noktasında mantıksal bir çerçeve çizebilen bir yöntemdir.

- Dördüncü olarak değer zinciri analizi; çeşitli nihai pazarlar için zincir faydalanıcılarının kimler olduğunu belirleyen ve söz konusu faydalanıcıların zincire girme noktasında karşılaşabilecekleri engelleri tanımlayan bir yöntemdir. Bu bağlamda turizm değer zinciri, özellikle zayıf nitelikli (yerel halk gibi) katılımcılarının zincire katılımlarını kolaylaştırabilecek en iyi fikre odaklanmalarını sağlayan bir analizdir. Bu noktada turizm değer zinciri analizi zayıf nitelikli katılımcıların; verimlilik sistemini geliştirme, ürün kalitesini arttırma, ürün farklılaştırma, sosyal ve çevresel standartları dikkate alma ve iş ortamına önem verme gibi değer zincirine katılımı kolaylaştıracak unsurları göz önünde bulundurmalarına olanak sağlayabilmektedir.

- Beşinci olarak değer zinciri analizi; doğal olarak ölçeklenebilen bir analizdir. Bu önemli bir ayrıntıdır, çünkü değer zincirinin başarısı sadece birkaç halkanın faydalanması üzerine değil tüm halkaların yararı üzerine odaklıdır. Bu bağlamda turizm gibi birçok sektörle entegre olmuş bir değer zincirinin tek odağının bir üretici grubu ya da bir işletme olması çok da tercih edilen bir durum değildir. Aksine; turizm değer zincirinin belli bir bölgeye ya da ülkeye uygulanmasının daha doğru bir analiz uygulaması olabilmektedir.

- Altıncı olarak değer zinciri analizi; göreceli olarak kanıta dayalı ve eylem odaklı bir analizdir. Dolayısıyla turizm değer zinciri analizi, işletmelere belirli noktalarda rekabet güçlerini arttırmak ve gelişimlerini hızlandırabilmek adına somut öneriler sunabilmektedir.

- Son olarak değer zinciri analizi; bir politika ve yeniden yapılandırma aracı olarak faydalanıcılarına ileriye yönelik açık ve net bir yol haritası sunabilen bir analizdir. Bu bağlamda turizm sektöründe değer zincirini oluşturan her bir halka arasındaki güçlü 
işbirliği, sektörün rekabet gücünü arttıracak ve sektörün gelişimine hız kazandırabilecektir. Aynı zamanda özellikle de destinasyondaki yerel halkın turizm değer zincirinin önemli bir parçası olarak görülmesi ve zincire dahil edilmesi de sektörün küresel rekabet gücün arttırabilecek bir süreçtir.

Söz konusu gerekçeler incelendiğinde; değer zincirlerindeki temel noktanın "her zincirin en zayıf halkası kadar güçlü olduğu gerçeği" olduğunu ifade etmek mümkündür. Dolayısıyla her sektörde olduğu gibi turizm sektöründe de küresel rekabeti sağlamanın kilit noktası, zincirdeki bütün paydaşların ortak hareket etmesini sağlayabilmektir. Yukarıda sıralanan unsurlar dikkate alındığında, özellikle az gelişmiş ve gelişmekte olan ülke destinasyonlarında turizmin etkilerini arttırmak ve destinasyonun kalkınmasını ve gelişimini sağlamak üzere bir yol haritası belirleyebilmek söz konusu olabilecektir.

\section{SONUÇ}

Turizm faaliyetlerinden faydalanmak üzere yola çıkan bireyler seyahatlerinde; ulaşım, konaklama, yeme-içme, eğlence gibi her biri ayrı ayrı birer ürün olan turistik ürünlerin, toplu halde bir arada sunulmasını beklerler. Söz konusu turistik ürünler turizm sektörü ile doğrudan bağlantılı faaliyetlerdir. Bununla birlikte turizm sektörü ile doğrudan bağlantılı olmayan ancak, sektöre bir şekilde dahil olan (inşaat, mobilya, sağlık, kurum ve kuruluşlar vb.) faaliyet grupları da söz konusudur. Dolayısıyla turizm değer zincirinin halkalarını oluşturan aktörler destinasyonda gerçekleşen turizm faaliyetlerinin içeriğine göre; konaklama, yeme-içme, eğlence, seyahat, alış-veriş, sağlık, inşaat gibi birçok faaliyet alanı ve işletmeden oluşmaktadır. Aynı zamanda, söz konusu tüm bu faaliyet alanları ve işletmelerde gerek istihdam olanağı bulan gerekse de ürün tedariki sağlayan yerel halk da turizm değer zincirin temel halkalarından birisi durumundadır. Değer zincirlerindeki temel noktanın "her zincirin en zayıf halkası kadar güçlü olduğu gerçeği" olduğunu ifade etmek mümkündür. Dolayısıyla her sektörde olduğu gibi turizm sektöründe de küresel rekabeti sağlamanın kilit noktası, zincirdeki bütün paydaşların ortak hareket etmesini sağlayabilmektir.

Turizm değer zinciri analizi, özellikle az gelişmiş ve gelişmekte olan ülke destinasyonlarında turizmin etkilerini arttırmak ve destinasyonun kalkınmasını ve gelişimini sağlamak üzere bir yol haritası belirleyebilecek bir analiz yöntemidir. Çünkü turizm değer zinciri analizi, üretim sürecinden başlayarak ekonomik getirileri temsil eden sadece sayılar ile ilgili bir analiz değildir. Turizm değer zinciri; fonksiyonel aktiviteler, hizmet sağlayıcılar, müşteriler, destek kurum ve kuruluşlar ve de tedarik zincirleri arasındaki ilişkileri tanımlayan bir zincirdir. Değer zinciri analizi çalışmalarının geneline bakıldığında, işletmeler ya da sektörler arasında sistematik rekabetin sağlanabilmesi için, hem zincirin halkaları içinde hem de zincir boyunca kuvvetli işbirliği sağlanması gerekliliği ön plana çıkmaktadır. Turizm sektörü paydaşları arasındaki ilişkiler ve bağlantılar, sektörünün faaliyetleri kapsamında ortaya çıkar ve bu faaliyetlerden doğan maliyetler de doğal olarak birbirini etkiler. Bu durumda, paydaşlar arasındaki bağlantının ve tutarlılığın etkinliği rekabet avantajını da beraberinde getirir. Dolayısıyla turizm sektöründe de küresel rekabetin sağlanabilmesi, zincirdeki halkaların her birinin dikkate alınması ile mümkün olabilecektir.

Turizmde değer zinciri analizi, ekonomik akımların turizmde nasıl işleyeceğinin anlaşılmasını sağlamayı, destinasyondaki farklı insan gruplarının (yoksul insanlar, gençler, kadınlar vb.) turizm harcamalarından aldığı payı analizler yardımı ile bölümlere ayırmayı amaçlayan bir 
analiz yöntemidir. Söz konusu bölümlendirme sayesinde hedef grupların herhangi birinin ya da hepsinin turizmden sağlayabilecekleri sosyo-ekonomik faydalar arttırılabilir ve destinasyonun rekabet gelişimine katkıda bulunulabilir Turizmin gelişme gösterdiği destinasyonlarda, turizm değer zincirinde yer alan paydaşların sektörle ve birbirleri ile etkileşime girmelerinin, tüm kesimlere fayda ve kazanım olarak geri döneceğini ifade etmek mümkündür. Söz konusu kazanımları; istihdam fırsatları, yerel ve yöresel ürün satışı ile doğrudan gelir kazanımı, altyapı yatırımları, destinasyonda yeni hizmet alanlarının oluşturulması, eğitim ve girişimcilik olanaklarının arttırılması gibi hem destinasyonda faaliyet gösteren özel sektöre hem de destinasyonun ev sahibi yerel halka faydalar sağlayacak fırsatlar olarak sıralamak mümkündür. Ancak burada dikkate edilmesi gereken nokta, elde edilen kazanımların turizm değer zinciri boyunca özellikle de yerel halkın net faydalar elde edebileceği şekilde orantılı ve adil dağılımını sağlayabilmektir. Bu bağlamda da paydaşların katılım düzeylerini ve söz konusu sosyoekonomik faydaları çözümlemenin yolunun, turizm değer zinciri modelini anlayabilmekten geçtiğini ifade etmek mümkündür.

\section{KAYNAKÇA}

Ashley, C. and Mitchell, J. (2008). Doing the Right Thing Approximately Not the Wrong Thing Precisely: Challenges of Monitoring Impacts of Pro-poor Interventions in Tourism Value Chains. London: Overseas Development Institute.

Bahar, O. and Kozak M. (2007). Advancing Destination Competitiveness Research: Comparison Between Tourists and Service Providers, Journal of Travel and Tourism Marketing, 22 (2), 61-71.

Blocher, E. J., Stout, D. E. and Cokins, G. (2010). Cost Management: A Strategic Emphasis (Fifth Edition). New York: McGraw-Hill.

Çil Yavuz, N. (2006). Türkiye'de Turizm Gelirlerinin Ekonomik Büyümeye Etkisinin Testi: Yapısal Kırılma ve Nedensellik Analizi, Doğuş Üniversitesi Dergisi, 7 (2), 162-171.

Dekker, H.C. (2003). Value Chain Analysis in Interfirm Relationships: A Field Study, Management Accounting Research, 14 (1), 1-23.

El-Sayed, A.M., Dickson, M.W. and El-Naggar, G.O. (2015). Value Chain Analysis of the Aquaculture Feed Sector in Egypt, Aquaculture, 437, 92-101.

Evans, N., Campbell, D. and Stonehouse, G. (2004). Strategic Management for Travel and Tourism, England: John Wiley and Sons Publications.

Gereffi, G. (1994). The Organization of Buyer-Driven Global Commodity Chains: How U.S. Retailers Shape Overseas Production Networks. Gereffi, G. and Korzeniewicz, M. (Eds.), Commodity Chains and Global Capitalism, London: Praeger.

Goeldner, C. R. and Ritchie, J. R. B. (2009). Tourism Principles, Practices, Philosophies (Elevent Edition). New Jersey: John Wiley and Sons, Inc.

Guabiroba, R.C.S., Meireles da Silva, R., Cesar, A.S. and Viera da Silva, A.A. (2017). Value Chain Analysis of Waste Cooking Oil for Biodiesel Production: Study Case of One Oil Collection Company in Rio de Janeiro-Brazil, Journal of Cleaner Production, 142, 3928-3937.

Hellin, J. and Meijer, M. (2006). Guidelines for Value Chain Analysis. http://ftp.fao.org/es/esa/ lisfame/guidel_ValueChain.pdf (24.09.2018). 
Hergert, M. and Morris, D. (1989). Accounting Data for Value Chain Analysis, Strategic Management Journal, 10 (2), 177-188.

http://www2.unwto.org/content/why-tourism (17.01.2017).

Ilgaz Yıldırım, B., Yıldırım, F. ve Gülmez, M. (2017). Türkiye' de Enflasyon ve Turizm Gelirleri İlişkisi Üzerine Ekonometrik Bir Analiz, Uluslararası İktisadi ve İdari Bilimler Dergisi, 3 (1), 69-81.

Jaligot, R., Wilson, D.C., Cheeseman, C.R., Shaker, B. and Stretz, J. (2016). Applying Value Chain Analysis to Informal Sector Recycling: A Case Study of the Zabaleen, Resources, Conservation and Recycling, 114, 80-91.

Kakoudakis, K.I., McCabe, S. and Story, V. (2017). Social Tourism and Self Efficacy: Exploring Links Between Tourism Participation, Job-Seeking and Unemployment, Annals of Tourism Research, 65, 108-121.

Kaplinsky, R. and Morris, M. (2000). A Handbook for Value Chain Research, Ottawa: IDRC.

Messner, D. (2002). The Concept of the "World Economic Triangle": Global Governance Patterns and Options for Regions, UK: Institute of Development Studies.

Mete, B. and Acuner, E. (2014). A Value Chain Analysis of Turkish Tourism Sector, International Journal of Business and Management Studies, 3 (2), 499-506.

Mitchell, J. and Phuc, L. C. (2007). Final Report on Participatory Tourism Value Chain Analysis in Da Nang, Central Vietnam. London: Overseas Development Institute.

Mitchell, J. (2012). Value Chain Approaches to Assessing the Impact of Tourism on Low Income Households in Developing Countries, Journal of Sustainable Tourism, 20 (3), 457-475.

Perles-Ribes, J. F., Ramon-Rodriguez, A. B., Sevilla-Jimenez, M. and Moreno Izquierdo, L. (2016). Unemployment Effects of Economic Crises on Hotel and Residential Tourism Destinations: The Case of Spain, Tourism Management, 54, 356-368

Porter, M. E. (1985). Competitive Advantage: Creating and Sustaining Superior Performance: With a New Introduction, New York: Free Press.

Proença, S. and Soukiazis, E. (2008). Tourism as an Economic Growth Factor: A Case Study for Southern European Countries, Tourism Economics, 14 (4), 791-806.

Raikes, P., Jensen, M.F. and Ponte, S. (2000). Global Commodity Chain Analysis and the French Filière Approach: Comparison and Critique, UK: Institute of Development Studies.

Samırkaş, M. ve Bahar, O. (2013). Turizm, Yoksulluk ve Bölgesel Gelişmişlik Farklılıkları, Ankara: Detay Yayıncilık.

Slob, B. and Wilde, J. (2006). Tourism and Sustainability in Brazil-The Tourism Value Chain in Porto de Galinhas, Northeast Brazil. Netherlands: SOMO-Centre for research on Multinational Corporations.

Spenceley, A., Ashley, C. and Kock, M. (2009). Tourism-Led Poverty Reduction Programme (Core Training Module). ITC (International Trade Centre).

Springer-Heinze, A. (2007). ValueLinks Manual: The Methodology of Value Chain Promotion, ValueLinks Module 2. Germany: GTZ.

Travers, R. (2007). Tourism Value Chain Analysis for the Trans-Asian Road 9 in Lao PDR and Vietnam. SNV Netherlands Development Organisation. 
Vignati, F. and Laumans, Q. (2010). Value Chain Analysis as a Kick off for Tourism Destination Development in Maputo City. Paper Presented at the International Conference on Sustainable Tourism in Developing Countries, August, Zanzibar, Tanzania

Wallerstein, I. (1974). The Rise and Future Demise of the World Capitalist System: Concepts for Comparative Analysis, Comparative Studies in Society and History, 16 (4), 387-415.

Walters, D. and Jones, P. (2001). Value and Value Chains in Healthcare: A Quality Management Perspective, The TQM Magazine, 13 (5), 319-335. 